\title{
Tenon's capsule granuloma at the donor site after conjunctival grafting - short report
}

Granuloma da cápsula de Tenon em área doadora de retalho conjuntival - Relato curto

Patrícia Ioschpe Gus ${ }^{1}$

André Cartell ${ }^{2}$

Samuel Rymer ${ }^{3}$

Sérgio Kwitko ${ }^{4}$
Study carried out at Hospital de Clínicas de Porto Alegre

${ }^{1}$ Professor of Ophthalmology, Faculty of Medicine, Universidade Luterana do Brasil, Porto Alegre.

2 Professor of Pathology, Faculty of Medicine, Universidade Federal do Rio Grande do Sul, Porto Alegre.

${ }^{3}$ Chairman Professor of Ophthalmology, Faculty of Medicine, Universidade Federal do Rio Grande do Sul, Porto Alegre.

${ }^{4}$ Ophthalmologist of the Department of Ophthalmology, Hospital de Clínicas de Porto Alegre.

Endereço para correspondência: Rua Quintibo Bocaiúva, 1035/201 CEP 90440-051 - Porto Alegre (RS) E-mail: guga@orion.ufrgs.br

Recebido para publicação em 18.03.2002 Aceito para publicação em 30.10 .2002

Nota Editorial: Pela análise deste trabalho e por sua anuência na divulgação desta nota, agradecemos ao Dr. Marinho Jorge Scarpi.

\section{A B S T R A C T}

Purpose: To describe a rare complication at the donor site of conjunctival transplantation. Methods: The authors report the clinical, surgical, postoperative and histologic aspects of a Tenon's granuloma that followed an uneventful pterygium excision with conjunctival transplantation. Results: Histology identified an hemangiomatous-like structure with some areas of foreign body granuloma overlying necrotic epithelial cels, easily excised surgically. Conclusions: Pyogenic granuloma is an inadequate term to describe an inflammatory nonsuppurative reaction that may follow uneventful conjunctival surgery in susceptible individuals.

Keywords:Ganuloma, pyogenic/anatomy\& histology;Pterygium/surgery;Conjunctiva/ transplantation

I N T RODUCT I ON

Conjunctival grafting for ocular surface disorders has become more popular over the past decade. Indications of either autograft or allograft conjunctival transplantation depend basically upon the patient's eye conditions, and can be very useful in reconstructing the ocular surface in different situations: primary and secondary pterygium excision, decreasing its recurrence rate from 70 to $7 \%$ when compared to the bare-sclera technique; advanced ocular cicatricial pemphigoid and Stevens-Johnson syndrome; burns; cicatricial trachoma and corneal injuries caused by soft contact lenses and refractory to clinical management. The harvest site of conjunctival donation usually heals spontaneously without complications, but may rarely develop into Tenon's capsule granuloma or fibrosis ${ }^{(1-2)}$. We decribe a case of Tenon's capsule granuloma in a previously healthy donor eye and discuss its pathophysiology.

\section{CASE REPOR T}

A 42-year-old white male was referred to the "Hospital de Clínicas de Porto Alegre" for treatment of a primary pterygium on the right cornea. Best corrected visual acuity was 0.6 . Pterygium resection using the bare-sclera technique and conjunctival autografting from the superior bulbar area of the patient's fellow eye were performed. The recipient site was first patched with a steroid-antibiotic ointment for two days and then treated with the same steroid-antibiotic eye drops for one month. Follow-up was uneventful.

The harvest site was allowed to heal spontaneously and $0.5 \%$ fluorometholone eye drops were prescribed for one week, applied four times a day. In spite of that, the donor's eye developed a vascularized, pedunculated and 
well-defined lesion measuring 3.5 x $4.25 \mathrm{~mm}$ (Figure 1). After excision, histology disclosed a circumscribed lesion uncovered by epithelium, in a lobular arrangement, and showing endothelial proliferation with formation of capillary lumina. Capillary lumina varied from small and cleft-like to ecstatic shape. Many of them were lined with prominent endothelial cells projecting into the vessels' lumina. Stroma in which the capillary proliferations were embedded separated the vessels, appeared edematous and showed young fibroblasts and hemosiderin. There was a foreign body granuloma involving necrotic epithelial cells in some fields. Inflammatory exudate overlying the surface of the lesion could also be seen.

\section{I S C US S I ON}

Histopathologic examination revealed a microscopic structure much more similar to a hemangiomatous organization than to a florid proliferation of granulation tissue ${ }^{(3)}$. Tenon's capsule granuloma, sometimes erroneously called "pyogenic granuloma", is a benign vascular tumor of mucous membranes and skin, more commonly found on the fingers, face and gingiva. The lesions tipically develop rapidly over a period of weeks to maximum size of 0.5 to $2 \mathrm{~cm}$; they are soft or moderately firm, elevated, and slightly pedunculated ${ }^{(3)}$. Ultrastructural studies have confirmed that "pyogenic granuloma" is a tumor of vessels and endothelial cells, and may represent small acquired arteriovenous fistulae ${ }^{(3)}$. It is not a supurative inflammatory response as the name suggests. Spontaneous involution is uncommon, and usually there is no cause for these lesions, although a few cases follow trauma ${ }^{(3)}$.

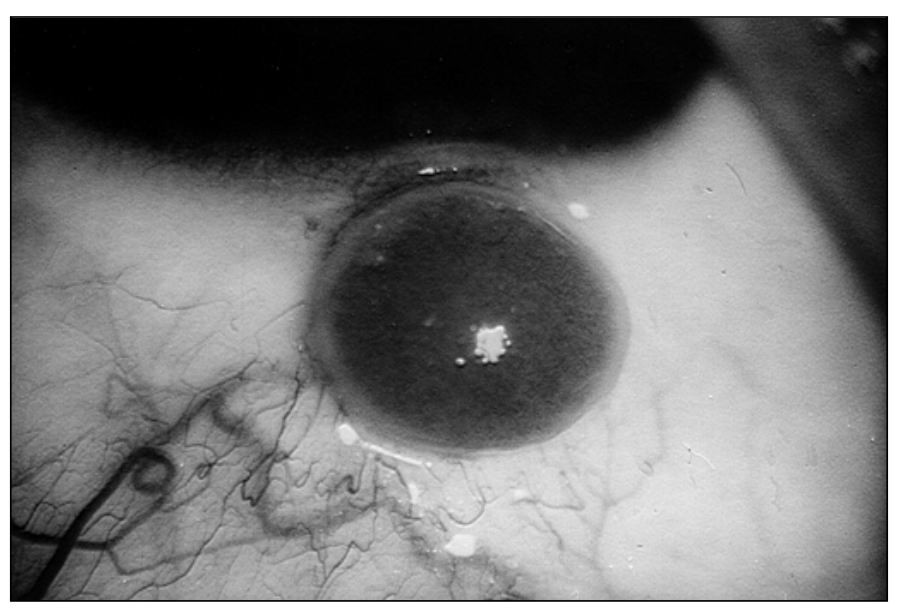

Figure1-Vascularized, pedunculatedandwell-definedlesionmeasuring $3.5 \times 4.25 \mathrm{~mm}$
The explanation for the development of this kind of healing process is merely speculative. Some authors advocate that exposure of Tenon's capsule with permanent friction of the upper eyelid can lead to an overgrowth of the exposed tissue $^{(1)}$. Another possible explanation is that, as observed in the frozen section, the fragile epithelium that covers the recipient site can easily erode and a foreign body granuloma develops around the necrotic epithelial cells that are not removed by blinking.

We have had two other similar cases, that were also surgically removed leaving no sequelae in the donor's eye. They were clinically identical to the case herein described, although histology was not available in any of them.

Even if it does not cause serious sequelae in the eye, scaring may complicate individual healing. We do not know, for example, whether these patients could develop Tenon's capsule fibrosis, a more serious situation that could compromise ocular motility. We suggest that patients with Tenon's capsule granuloma be closely evaluated with regard to their mucocutaneous healing, and further studies should be performed to elucidate pathophysiology of this condition.

\section{R E S U M O}

Objetivo: Descrever complicação rara em área doadora de retalho conjuntival. Métodos: Os autores descrevem os aspectos clínico, cirúrgico, pós-operatório e histológico de granuloma da cápsula de Tenon em área doadora de conjuntiva que seguiu cirurgia não complicada de excisão de pterígio com transplante conjuntival. Resultados: $\mathrm{O}$ exame histológico evidenciou estrutura tipo hemangiomatosa com áreas de granuloma de corpo estranho envolvendo células epiteliais necróticas. Conclusão: Granuloma piogênico é nomenclatura inadequada para descrever reação inflamatória não supurativa de fácil excisão cirúrgica que pode seguir a retirada de conjuntiva em pacientes suscetíveis.

Descritores: Granuloma piogênico/histologia; Pterígio/cirurgia; Conjuntiva/transplante

\section{REF E R E N C E S}

1. Starck T, Kenyon KR, Serrano F. Conjunctival autograft for primary and recurrent pterygia: surgical technique and problem management. Cornea 1991;10:196-202.

2. Vrabec MP, Weisenthal RW, Elsing SH. Subconjunctival fibrosis after conjunctival autograft. Cornea 1993;12:181-3.

3. Strutton G, Stenn KS, Goldenhersh MA. The skin. In: Symmers WStC, editor. Systemic pathology. Edinburgh: Churchill Livingstone; 1992. p. 953-4. 